\title{
論
}

文

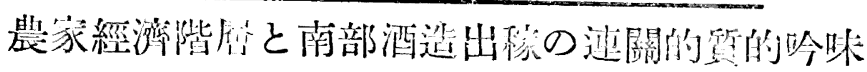

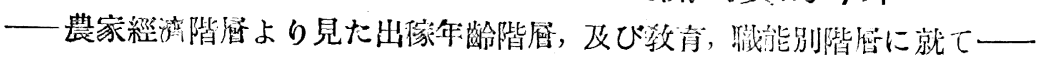
川本忠平

筷者は第 1 報として南部進出榢給源地域の 概括をなしたが, Saison Arbeiter としての 當出稼が费家經濟之如何なる關速を有寸万か。

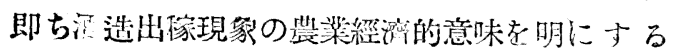
ことに低つて酒造勞力移鞋の队面的性格を把挵 しょうと誈みたのである。斯かる立場より既に 選定村志和村（岩手跞紫波郡）の。 村民階展, 業態階展别出稼, 農家 經營规模別出稼, 土地所有階管别 出稼情况等の分析を詀み、て來たの であるが, 更に年齡別出傢，並に呚 育的階展, 職能的階原别出稼情况 を農家經涪展との關倸に於て分 析,吟味してみたいと思う。

選定村志稩村流南部杜氏發神地とし て古くより河造出碇給源の中核地域 なつて來たのであるが，昭和16年度に

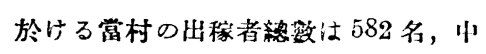
第 I表

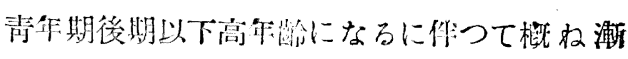
減的傾向を示すが，而し壮物期後期（35オー39 苛)に於てや小少減し, 老作期前期 (40才ー49

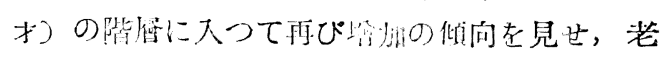

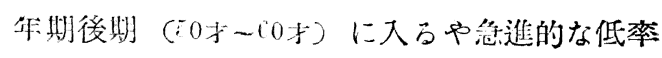
を示し，60才以後には壮热

酒造出稼者比 430 名を占的全体 $074 \%$ が賞出稼者である。河造出稼者 430 名小，南部恃氏組 合に㧈入している老298名，非㸝入者132名であり， 之等に就ての調查を試みた。

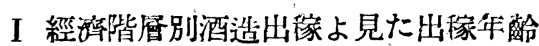

農包杜氏としての移動者和龄の考察は酒造的 稼の質的檢討の上から重要な一部門を構成する と思う。殊に持術的勞力を媒介とする季節的移

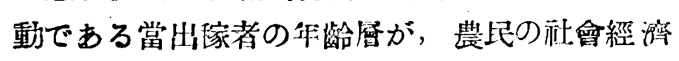
的條件や，農家の經濟的位置の差異に低つて 如 何なる特性を示すかの問題は興味方万課題です ろ。こつに於て志和村を上.中下の 3 階居 (巨数

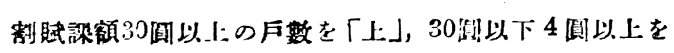
「中」，4司以下「「「」とせしのである)に分ち，

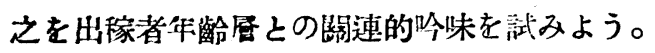

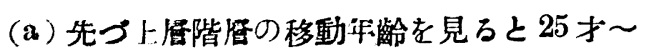
2打至万青年期後期に最多人（28.6\%）， 30才〜34才の壯年前期が之に二次ぎ $(15.5 \%)$ ， 15才〜19才に亘万少年期後期居が (11.7\%) 第 3位の移動性を示している。

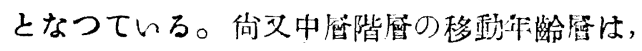

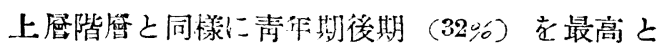
乙, 壯年期前期 $(19.1 \%)$ ，少年期後期 $(1 \%$ ) が之に次ぎ，上展のそれと同年路愿に最高移動 性を示している。しかし壯年期前期以下高年、蕶

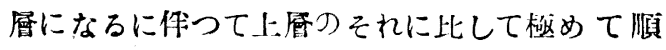
序正し的減少を示す。更に之か下凰階展に至つ て吖, 矢張り前 2 者之同樣青年期後期 (27. $1 \%)$ が最高移動性を有するが，唯少年期娞期が第 2 位（19.1\%：を占め前 2 者よりも少年结に若干 の篦加傾向を見せている。又壯年期前期以後老

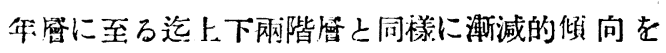
巡乃が，唯比較的老平居末期に於ても可成りの 移動傾向を示している事活見逸せない。

從つて上.中下の各階居を通しての移動の比重 は25お〜2」おの青年後期に最も重く且つ之が支 配的移動年跲㕣であると見做される。

又之に次ぐ移動㫮深は壯年期前期に現れて いるが，しかし下盾階后に至つては少年期後期 が第 2 位を䏡」:詹一下底に低下するにつれ 


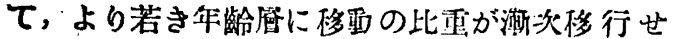
ん亡する傾向が現れている。しかし聜ろ之とは

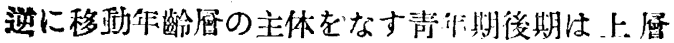
一下磨に至るに從つて移政比重の低下する仳

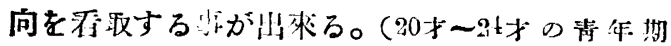

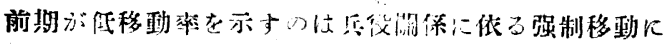
基く絬果である。) 佔最も注意すべきは，多少の

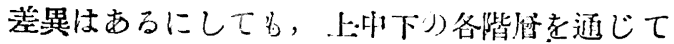

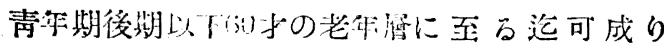
の移汸率を付方策である。

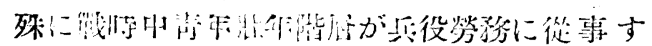

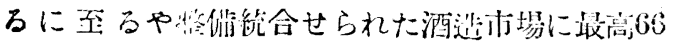

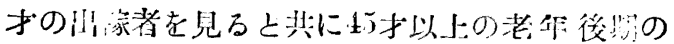

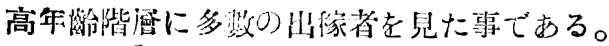

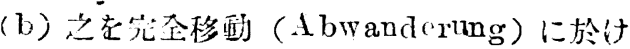

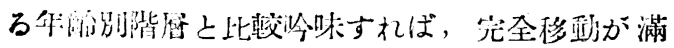

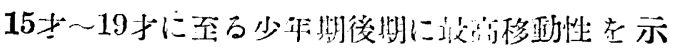

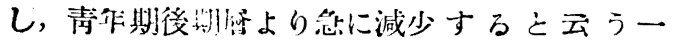

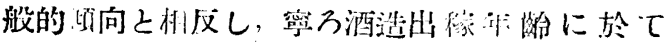

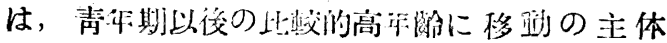

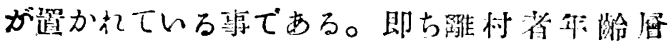
が15才〜19才の忧だ家达的煩累を佮せず，又

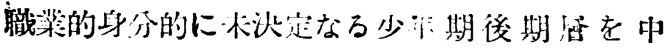
心として行われるに反し，窝万不完全移動 (Unperiodishə Wanderung) としての酒造 出榢が堄に家尤し責任的地位にあり，農村生活に

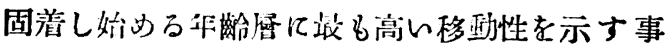

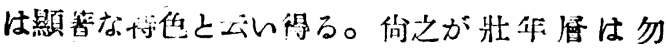
論，老年憎に至万階展に迄現れている事賽は，彼

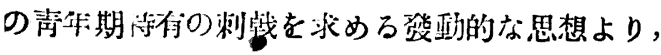

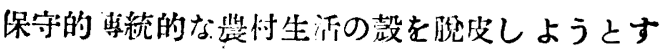
ろ向都背村の羅村移動とは著しい相異性を認め 得らのである。既に一家の責任者であり譨家經

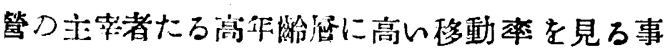
は，転村に周定化した階詹，或は周定化せんと

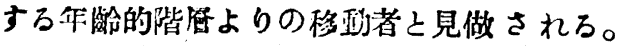

又完全移動省年路居が上居から下居に移るに 等いより若き少作期移動が促進せられると云う 一般的傾向之比较寸万時, 酒造出稼年路がより 下腒部に，や小高き少作很移動率を示した事 さ，完全移鲀にそれと類似する移動傾向上云い 昌万のであう。併し作ら支配的移動年龄后て
ある青年期後期が.上手一下屏に移行するに件 んや」低い移動率を示し，嚾村移動とは窑乃逆 の)倾向を有する事は注目すべきである。

(c)以上の分析を綜合しつょ一應の要約をな せば次の如にくなる。

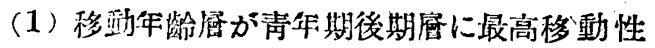

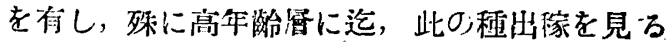
ことは，酒造營価が䎌なる竹肉的勞働でなく， 身侑的技衔を桨介とした移動營働である事を物 琵るものである。面に農村民中堅年烣會及び高

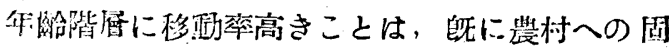

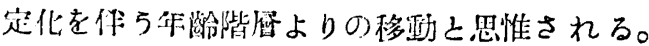

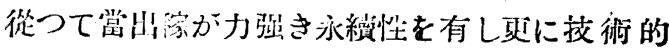

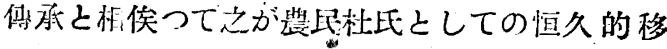
動性を提示するものと見做し得る。

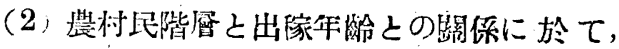
各階管共青尔期後期が最嵪移動性を有子ると踓 も上居より下居に移るに從つてゃ小低率を示す 之同時に，少年期後期は之之通に僅少の增率を 示している。斯の如く經济的上居階層に移動 の高率を見るのは，嘗ての研究に於て專㻃階首 の經㳽的上㞕部に最高移動率を見た事，及び農 家經營規模の比較的大なる階唇 (3町一)町末滿) に高い移動傾向を示した事, 或は土地所有關係 より地主階屋が小作階屋に次ぐ移動性を有した 事,等之同じ性格を有し，當出稼が單なる經湾的 理由にのみ农乃貨勞働化現像でないよ云う酒造 出稼の特徴の一端を物語るものであろう。併し 下扈階首に於けろ少年期後期の移動が上居の之 れより增率を示し，又比較的より老年層に迄出 稼移動を見万事は，恰 も完全移動に見万移動傾 向之類似しており，此の點より經汤的收益化を 直接の動機としたものと考えられる。向之は專 農階展の下居經渓農家が上㸴のそれに次ぐ移動 率を示した事，又農家經營規模の比晈的小なる 農家 (5反〜1町步未滿) よりの出稼が最高移動 を有した事，或は小作農家が地主のそれよりや \高率の移動を示した事, と同じ傾向を示に。 ている。從つて酒造出稼者は青年期後期壯年期 前期厚を中心とする各階屋よりの出身者で占め られているとは云え，其の出稼動機に於て直接 殌涪的要求に基くものと當地方に於ける歷史的 移動性に依乃出稼者階層の 2 面的性格を是認し 得るのである。 
之を總括的に見ると上中下の各經流階層を通 して相當高年歎に至る迄，ほ心゙同調的な出稼率 を示す事は抆術的出稼たる酒造勞㗢に基因する ものであり，又恒久的歴史的移㳩性が經沾的階 層性を或程度越えた移動を提起せしめている事 を物語るものである。

\section{II 酒造出稼者の教育程度の分析}

酒适營働者の質の判定には相々の問題が存 在 するが，そを㸚能度に於て見る限り如们なる 人口が移汮しつ」あるか。訽諭㸚育程度の如们 を以て直ちに人間の素㳩の優劣を論ずるこ上は 相當なる危險を作うものである。作し現在の敎 亩が人間性の缸治を日指した品性の助成作用で あろ以上，一般に㸚育牦き者に比して㸚育ある 人間の品性, 就中知能レベルの高いことは當然 であろう。斯から意味より出稼者の呚育程度の 吟味を通して Saison Wanderung たる當出 稼の特徵を見ようとしたのである。

志和村の 430 名の出稼者に就て調查するに, (a) 先ず學校に入學せさる者, 即ち無㪍育階

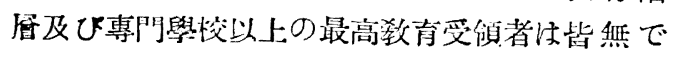
ある。之を學校程度別に見万之, 中學校卒業者 は中途退舉をも加えて全移渜者の $3 \%$ に過ぎな く, 從つて出榢者の知能的水準を表す敉育程度 は、, $3 \%$ 占めろ中等學愎以上の者を除けば尋裳
第 2 表 酒趓出稼者の㸚育的階戶

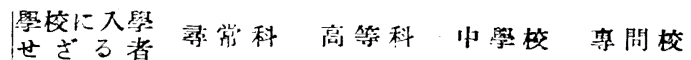

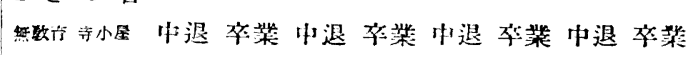

\begin{tabular}{|c|c|c|c|c|c|c|c|c|c|c|c|}
\hline \multirow{2}{*}{ 䇛 } & \multirow{4}{*}{0} & \multirow{4}{*}{0} & \multirow{4}{*}{0} & 8 & 4 & \multirow{2}{*}{$\begin{array}{l}60 \\
86\end{array}$} & \multirow{2}{*}{$\begin{array}{l}0 \\
2\end{array}$} & \multicolumn{2}{|l|}{5} & \multirow{4}{*}{0} & $7 \pi$ \\
\hline & & & & 45 & 18 & & & 2 & 0 & & $15 \mathrm{t}$ \\
\hline 下 & & & & (i4 & 35 & 96 & 2 & 1 & & & 199 \\
\hline 數 甜 & & & & 11.3 & 58 & 242 & 4 & $\delta$ & & & $4: 7$ \\
\hline \multirow{2}{*}{ 割 } & \multirow{4}{*}{0} & \multirow{4}{*}{0} & \multirow{4}{*}{0} & Ii) & 5 & 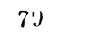 & 0 & 6 & & & 100.0 \\
\hline & & & & 30 & 11.6 & 56 & 1.2 & 1.2 & 0 & 0 & 100.0 \\
\hline 下 & & & & 322 & 18 & 48.3 & 1 & 0.5 & & & 100.0 \\
\hline 合 訢 & & & & 27 & 19.5 & 56.1 & 1.0 & 2.0 & & & 100.0 \\
\hline
\end{tabular}

の敎育的階居も文名んど見受けない。特に高卒 者が尋卒の䄪 2 倍の数老占め, 中學以上の敉有 受領者さ之若干之に參加しつ」ある傾向は，漁 菜出暴，或は鈸山勞働の如き主として筋肉的勞

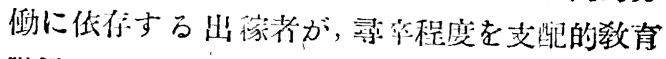
階糜さしでいるの之對比して注目すへき特徽と

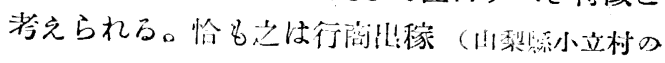

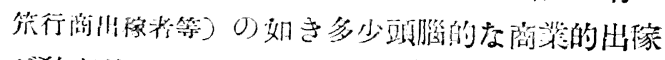

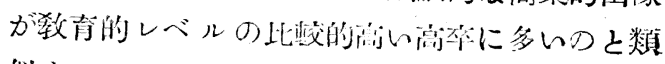

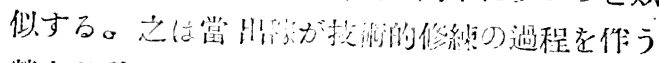

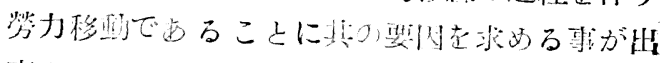
來よう。

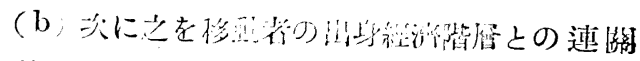

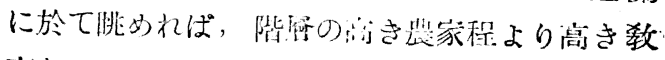

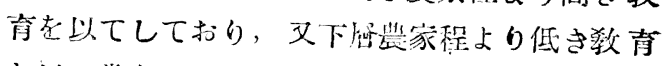

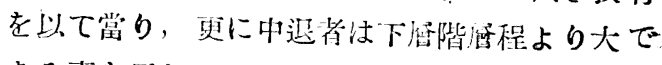
ある事を示している(籍2表參照)。從つて呚有

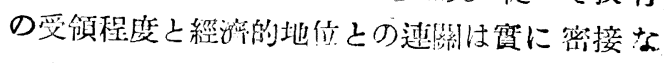
ろものがある事在首肯し得るが，们れの階展上

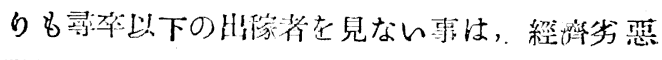

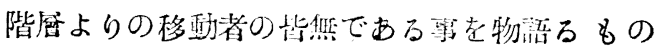

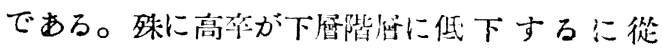

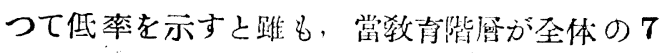
割をらめている矛は，虽村に於ける中位乃至は それ以上の經流的階原よりの移斬者が支配的移 動階厤であると見做し得るのであ る。しかし作ら中學卒蔧以上の出傢 者が始んど皆牦に近いことは最伐良。

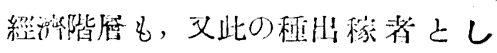

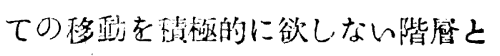
も考えられるのである。算孝は既に 出萣者の農家經淙的地位の笲明を企 圆した。それに依れば酒造洲榢者の 杜俞的經河的地位は必ずし女低位に あるとはいえない現状であり，㽦る

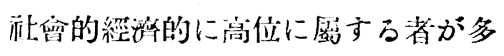
レことを明にした。文宸家經營規模 より見た山榢移勘に於て，小規模經

科卒業か, 高等科修了かの階庴となる。就中高 等科修了が全体の56 1\%を占め,之、に中退を加え れば約70\%の大多數を占めることになる。之に

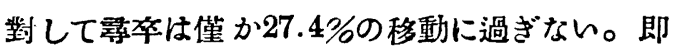
ち酒造出榢者は高等科修了程度が全体の 7 割を 占め，無㜞育な出稼者も無いかはり，中學以上

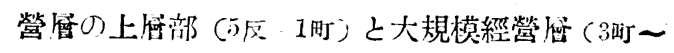
5 町末溯) に最も多く，小規模經營居の下居部 (5反未淽) 及び5朾步以上の大經營農家が最 低

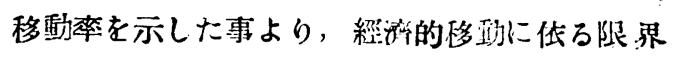
性之，歷史的移動性に基く出稼の限界性に就て 究明したのである。更に土地所有關係及び移動 
○年合的分析を通して, 或万程度の霍差性を持 つた中堅虽家，及び比較的上愿㖘家に移副率の 高い事を知り，又土地に周定化されつ」ある青 年期後期並に壯年期階曆が移轻の中核であつた 事をも究朋した。これらの事は前述した出傢者

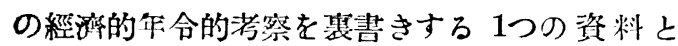
見做される。

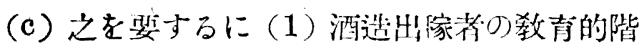
展の中核は當村全体から見て比政的教育程度高 き高卒者によつて支配的に惟成せられている牙 を認めると共に中學以上の敉青受頒者证に焎敉 育階展よりは多ど眥然である事をも是認しなけ ればならない。之が比較的呚青程度高き高卒に 多いこ上は常出榢が單なる闪体的勞墈ではな く，技術的幏亡しての性格に基くものと見做 される。又最高, 最低教有階低に全く其の移動 を見受けないこ上は，移䣦器働の犋的立場より 見た當泪傢の特彺の一端上云い得るであろう。

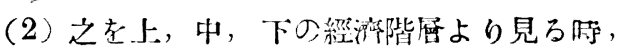
上筧程より离き教有を以てしており，下保程よ

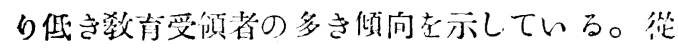

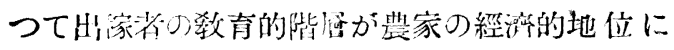
よつて漱次性格づけられつ」ある事在認め万 が，てれが高华に最も多く，下位は寻卒に限定 された教育的階展の䇭国性を持つことに注目す べきでをろう。

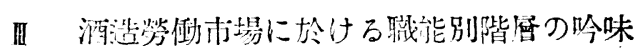
第 1 報にて酒浩落形態が棈氏を中核とする 血緣鄉黨的集園であることを朋にしたが，之が 技術的焱力の移嫁である点より，酒造术場に於 ける職能的階級組織を持つ事も又注目した處で あつた。即ち杜氏以下を螕稃して藏人之云い,

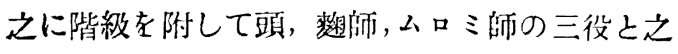
に從屬する「下倒き」がある。乞こで之等の酒造 市場に於け万職能的階級之, 農家經浪階展之の 間に如何なる關連があるかと云う考察は技衍的 勞力移動たろ酒造出傢の性格をより明白に提示 し得ると思う。

(a) 志和村の 43 !人に就て其の職能的分析古 なすに，掫高技術者である杜氏が全体の $12.8 \%$
第 3 表 酒洁出稼の職能別階原

\begin{tabular}{|c|c|c|c|c|}
\hline & 杜 氏 & 役 & 下值鬲 & 計 \\
\hline 上 & 18 & 33 & 26 & 77 \\
\hline 中 & 10 & 36 & 108 & 154 \\
\hline 下 & 27 & 46 & 124 & 199 \\
\hline 数 & 55 & 112 & 263 & 430 \\
\hline 制 上 & 23.4 & 43.0 & 33.6 & 100.0 \\
\hline 中 & 6.5 & 23.4 & 70.1 & 100.0 \\
\hline 下 & 13.5 & 24.1 & 62.3 & 100.0 \\
\hline 合 計 & 12.8 & 26 & 61.2 & 100.0 \\
\hline
\end{tabular}

之に次ぐ三役が $26 \%$ ，最も技街を要しないと見 倣される「下傎き」が61.2\%の大多數を占め，

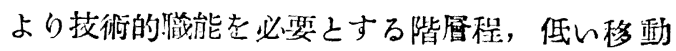
率を示している。之は朋に「下傎き」より身を 起して杜氏の資格を獲得する一速の過程が，技 泪的修練を䊾介上する事を物語るものにて，杜 氏が30才以上の高作命首に最も多いのも斯かる 技術的側面より生じたものである。殊に「下㗢 き」が約 6 割の多数を占めているのは，比较的 技街を要しない職能である事より自由に鉒加移 動し得る可能性を有するからであろう。

（b）决に之を農家經濟階庴との關係を吟味す るに，先ず上奋階唇に於ける職能別移動率は，

「三役」が最も多く(43\%)，「下働き」が之に 次ぎ (33.6\%)，最高技術者の「杜氏」が第 3 位 (23.4\% ${ }^{\circ}$ ) に位置している。併し上居階房に於て 第 3 位を示す杜氏移動率は, 上中下各階展のそ れと比较する洔，浸高の移動率を示している事 に注目すべきである。即ち比較的高き技街職能 階展である「三役」ボ上展部に最大移動率を有 し，又杜氏移動率が上居部に最も大である事 は，南部酒造出稼の指導的階笛が，上居農家階 詹からの出身者である事を示すものであり，同 時に之等は單なる經濟的誘引のみに依る移動で はなく，謂所歷史的移動性に基く勞力移動之見 倣し得るのである。

更に之は中㕣下居經狧階居を吟味する事によ つてより明瞭となる。 即ち中居階㕣の「杜氏」 は $(61.5 \%)$,「三役」(23.4\%),「下働き」(70.1\%), 下階扈の「杜氏」(13.6\%)，「三役」(24.1\%)， 「下働き」(62.3\%) となり,「杜氏」から「下 
働き」に至るに從つて移動は嬒加の傾向をと り，技術的制約の弱几「下働き」の移動が最大 を示している。併し中屋階菅に於ては「杜氏」 の移動最も少く，「三役」「下働き」に移るに 從つて急增的移動率を示し，「下㗢き」階唇に 於て各展中最大移動率を提起せしめている。份 下管のそれに於ても「杜氏」の移㳩 $13.6 \%$ を有 し中货のそれよりもや小漸㫮的移预率を示して レろのである。

從つて當地酒造出稼の指導的階倍える「杜

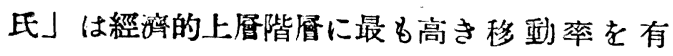
し，更に下局殌缼階居のそれが之に件うことを 認めうろ。之に反し雜没の下働き階首は中屡階 居に於て最大移動率を有し，上展のそれが最少 移動率を示しているが，一般的傾向として上ょ り下首經独居に至るに作い雜役階展の移動が增 加する傾向を看取する事が出來万。之は上展經 濟階居の「三役」及び「杜氏」のそれが，厢史 的移動性に基く出稼であるに反し明に經沙的要 因に基く勞力收益化形態の現れ之見做し得るの である。

（c）以上の分析に基いて之を總括するに，

（1）最高技術者たる杜氏出榢が最少數を示し， 技润的制約から解放される「下働き」出傢が最 大数を占める事は明に技術的修練を中㤥とする 勞力移動の性格を示すもの之云い得るですろ う。

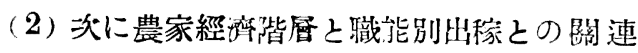
に於ては，2つの異つた移件局面がある。1つ は農家經唯階愿之密接な關係を有する移動面で あり，他は經濟的理由を越えて移㲜す万局面で あろう。即ち經濟的下居階居になるに伴つて

「下働き」出稼者の垻加する傾向を有し, 前節 の年合的階居別出稼に於て，下居階愿の少年期 後期（15才〜20才）に移動率の增加を見たのと 對比して，磼かに經濟的動機をより直接的原因 とする移動と見されろ。しかし之とは寗ろ逆 に，經濟的上屡階居に「杜氏」「三役」の比較 的高い移動率を見る事は歴史的移動性を道接の 動機とする移動之見做し得乃のである。

(3) 從つて南部酒造出稼の職能的性格は一般 的に最高技術者としての指導的地仿を經濟的上 辰階辰からの出身者が占めつ」あり，又之に反 し從属的な「下働き」出稼は中居，下居經独居
よりの出身者が艾配移動者であることを是認し 得ろのである。

（4）又中首階后に於ける「杜氏」が極少移動 性を示すにか」はらす，「下働き」が最高移動 率を有するのは，好何なる理山に基くか。此の 点に就ては未だ研究不充分なるも一應次の如く 考えられる。即ち村卫階愿别酒造出傢に於て中 愿階展む゙最低移㔚率を示した事，或は土地所有

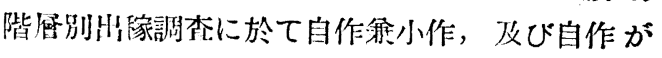

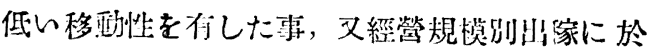
て2〜3衍步經營農家が昌低移動率を示し， 1 2 町末滿のこれが之よりや小高き移泟性を有して いた事等より，之等中屡階原は當地方に於ける

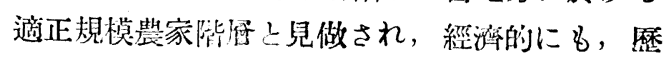
史的移政性:よりしても皘校的移㳩要因を持たな

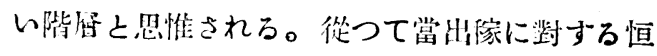

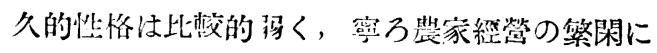

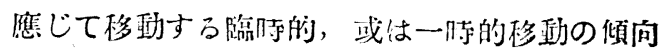
を行するものではなかろうか。

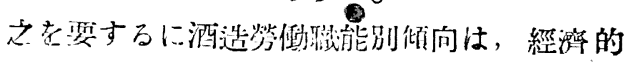
下唇部により多くの「下働き」出榢者を出し，

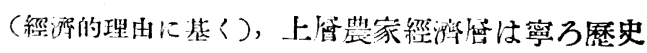
的移怔性に基く移功にて，之が酒浩归稼の指導 的地位を过めつ」ある事は當出䅝の䋶著な特徵 の一端と云い得るのである。

以上の分析に任的警上杜氏としての酒造勞働 が, 佮令的, 呚有的階虑及ひ職能的階居に於 て，Siison 性在作万技術的出傢の特色する性 格を提示することを認め, 且つ又, 之等が農家

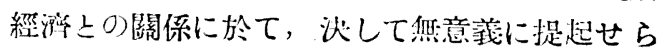

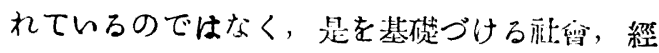
游的條作の存在す万事を是認し得らのである。 更に家族棬成員别山檬情况の究朋及び其の他の SaIson Arbiiter との比较任究に於て,より明 白に當出稼の筫的特色老把握し得万之思う。。

(25.4.13. 訅)

\section{考文献}

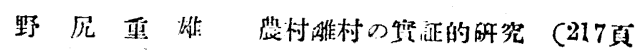

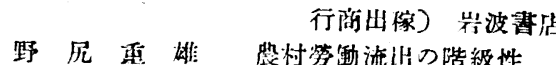

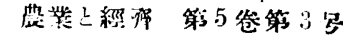

山本熊太部「恃氏」の出傢分们 地埋教育 16 管

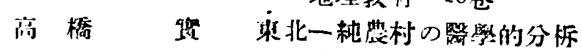
倠手縣登碀联合會

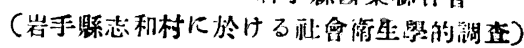

